\title{
The Empirical Study of Innovation and Marketing Strategy in the High Tech Products Context
}

\author{
Chih-Wen Wu \\ National Chung Hsing University, Taiwan
}

\begin{abstract}
:
The research identifies relevant gaps and addresses the research questions by using meta- analysis, phenomenology and FsQCA study. This study addresses innovation and marketing strategy within the context of high technology in Taiwan. The research argues that adopting innovation and marketing strategy increases the likelihood of success and sustain their competitive advantage. This research proposal addresses these questions by revisiting the external and internal environment force, innovation, marketing strategy and performance in the high tech industry context by using qualitative and quantitative methods. Research results and managerinal implication is discussed in the article.
\end{abstract}

Key words: High tech industry, innovation, marketing, meta-analysis, phenomenology, FsQCA 


\section{Introduction}

Innovation and marketing is crucial to globalization for the high tech industry. While marketing strategies are recognized as importance to organizations, very little research addresses how marketing strategies affect performance in the high tech products (Sarin and Mahajan, 2001;Rapp, Bachrach, Panagopoulos \& Ogilvie, 2014). However, high technology marketing is failure because most high tech firms focus on the technology and ignore the market. This main research purpose is to enhance our understanding of marketing and innovation strategy effectiveness for the high tech firms.

There is no standard measure of innovation and marketing strategy in the literature. A frequency count measure of innovation captures patents generated by the organization while some marketing studies use intention to adopt. For example, R\&D intensity and marketing intensity reflects innovation and marketing strategy. These measures reflect different components of performance. Therefore, previous studies find similar or different research results. Hopefully, this research identifies the antecedents and outcomes of innovation/marketing strategy and performance.

The research of innovation/marketing strategy and performance is fragmented. Several different theoretical approaches examine innovation and marketing research, little comprehensive model of innovation and marketing approach emerge within the literature. Because innovation/marketing strategies and performance are influenced by many different variables, little studies examines all of variables in one study(Brettel, Heinemann, Engelen \& Neubauer, 2011). Therefore, it is needed to build a comprehensive model to explain the performance differeence.

The research identifies relevant gaps in the literature where the research question is addressed by using meta-analysis, phenomenology and fsQCA study. This study addresses the performance and $R \& D$ and marketing strategy within the context of high technology in the science park in Taiwan. Hopefully, the research enables organizations to increase the likelihood of success for adopting innovation and marketing strategy and sustaining their competitive advantage.

The research provides a synthesis of the empirical literature and aids to the advanced knowledge development of innovation and marketing strategy by assessing theoretical models of innovation and marketing strategy antecedents and consequences. Second, this study addresses these questions by revisiting the external and internal environment force, innovation, marketing 
strategy and performance in the high tech industry context by using qualitative and quantitative methods. Specifically, his research addresses the following questions:

1. What is external and internal factors, innovation strategy, marketing strategy and performance accepted conceptualization in the high tech industry context?

2. How do internal and external environment affect innovation and marketing strategy?

3. How do internal and external environment affect organizational performance?

4. How do innovation and marketing strategy affect the organizational performance?

\section{Literature review}

\subsection{Innovation strategy research}

Innovation creates a sustainable competitive advantage and is an essential component of economic growth (Brown and Eisenhardt, 1995; Huarng, 2010, 2011; Cai, Tu, Liu \& Nguyen, 2015). Innovation is a key strategic activity and provides them for aligning with market conditions (Schoonhoven, Eisenhardt and Lyman, 1990; Dibrell, Graig \& Hansen, 2011), handling market dynamism(Kindstrom \& Kowalkowski, 2014) and improving performance (Dibrell, Crag and Hansen, 2011; Laforet, 2008; Reed and DeFillipp, 1991). Innovation serves as a key factor for better performance(Damanpour \& Evan,1984; Sarin \& Mahajan, 2001).

\subsection{Marketing strategy research}

Marketing strategy performance is defined as the extent to which a firm is able to develop a comprehensive marketing program by a firm (Andrews and Smith, 1996; Boehmn \& Hogan, 2013) and enhance performance (Fetscherin \& Usunier,2012; Gilson and Shalley, 2004). Marketing strategy research focuses on marketing program or marketing strategy process (Makkonen \& Johnston, 2014). Marketing strategy process research examines the development of marketing strategies. Marketing program examines how to implement of the 4P strategy (Moorman and Miner, 1997; 1998; Weick, 1998).

\subsection{The empirical studies of innovation and marketing}

The relationship between innovation and performance are positive for financial performance (Rapp et al.,2014) while other previous studies are negative(Greve,2003; Mishina, Pollock and 
Porac, 2004; Rubera et al., 2012). Innovation to have a positive effect on organizational performance (Moorman,1995; Souder \&Jenssen 1999), while previous has a negative, or no effect (Lukas, Bryan \& Ferrell,2000) on organizational outcome. Marketing strategy creates original and beneficial champiagn to the firms (Crossan, Cunha, Vera and Cunha, 2005; Song \& Song, 2010 ). Marketing strategy are drivers of organizational performance (Moorman and Miner, 1998). Marketing as a function faces a threat of extinction, or an increasingly reduced role in strategic planning and show their influence on innovations, and lead in performance outcome (Juga, 1999; Kim and McMillan, 2008; Stock et al., 2013).

\section{Research methodology}

The research carries out qualitative method including meta-analysis and phenomenological study for identifying marketing and innovation issues for the Taiwan Science Park. The research tests an empirical model by employing fsQCA.

The research also uses phenomenological design to explore the internal and external environment, innovation strategy, marketing strategy, and performance of a companies operating in the Science Park in Taiwan. The research conducts face-to-face semi-structured interview and explores and the perceptions of a convenient sample of 15 high tech managers of a group of companies operating in Taiwan Science Park. The research tapes and transcribes semi-structured interviews for data analysis followed by Moustakas's (1994) suggestion. The interview questions revolved after reviewing literature and meta-analysis. The method includes the following steps:

1. To classify marketing \& R\&D experiences into groups;

2. To determine the relevance of statements;

3. To examine the identification and elimination of applicable themes and clusters;

4. To validation and construct from clusters.

5. Researchers should not have personal judgment or bias.

The data obtained from semi-structured interviews and observations is stored, catalogued, and coded. The research uses Nvivo 9, a recognized software program for data storing, cataloguing, and coding purposes. The Nvivo 9 software assisted in ascertaining themes regarding the understanding of research construct. 
The research framework of this study is to understand from the perceptions and perspectives of a convenient sample of managers, information about research variables in the high tech firms in Taiwan. An understanding of the business experiences of qualified managerial employees in the Science Park provided insights about the research theme. Personal interviews are conducted with a convenient sample of 15 participants, working full time for firms in the Science Park in the high tech context. The study population is comprised of individuals in managerial positions, who had interacted with marketing and $R \& D$ as a criterion for their selection as participants. Only participants who will complete the interview and approve the transcriptions includes in the study.

Questionnaire is designed after literature review, meta-analysis and pre-test study. Further, the questionnaires are tested in a pilot study composed of high tech firm mangers to clarify ambiguous or misleading questions. This study collects data from marketing and R\&D managers in the science park in Taiwan. Managers are surveyed by using a mail questionnaire including external environmental forces, organizational capabilities, organizational learning, organizational structure, marketing strategy, innovation strategy. All questionnaire items are closed-ended and measure managers perceptions on seven-point from strongly disagree to strongly agree.

The study employs FsQCA software to test hypotheses. Ragin (2008) provide computer programs based on Boolean algebra that check for all those cases that demonstrate the outcome whether any condition is present to establish logical necessity and, for every logically possible groupings of case configurations whether the outcome is always present to establish logical sufficiency. Consistency indicates the degree to which the cases with the same causal condition or combination of causal conditions display the same outcome while coverage describes the degree to which the cases sharing the same outcome also show the same causal conditions or conjunctive statements. Comparable to strength in standard statistical methods, coverage assesses the empirical relevance (Ragin, 2009).

\section{Empirical Results}

The research obtaining the sample from online information of high tech firms in the Taiwan Science Park. This database yielded a sample of 1,024 companies. Hence, this process yields 287 replies. Finally, 251 valid high tech companies is the final sample. Table 1 provides details of the calibration of conditions. 


\section{Table 1 here}

The next step of the fsQCA process is to analyze necessary conditions constitutes. Table 2 shows results of this analysis.

\section{Table 2 here}

The research presents analysis of causal configurations that lead to performance by some influence factor. The fsQCA model for performance is as follows:

$\mathrm{Y}($ organizational performance-f $)=\mathrm{f}$ (external environmental forces-ef, organizational capabilities-oc, organizational learning-ol, organizational structure-os, marketing strategy-ms, innovation strategy-is)

This study examines the condition for determining performance. The conditions in this study are company size, marketing experience, $R \& D$ expenditure, marketing expenditure and government financial support.

Tables 3 present data relating to sufficient conditions for organizational performance. The consistency of all of these five configurations is greater than 0.75 , which indicates that they are sufficient for the outcome to occur.

\section{Tables 3 here}

This configuration has unique coverage of 0.724806 and consistency of 0.784507 . According to this combination of conditions, high tech companies with some kind of financial support and a founder with marketing experience, company size, and high marketing and innovation expenditure have better performance.

Table 4 explains the configurations that lead to bad performance. In this model, three causal configurations lead to bad performance (see Table 4). This low coverage indicates that no high tech firms profile leads to bad performance.

\section{Table 4 here.}

\section{Discussions and Implications}

This study examines contingent factors of high tech firms that affect performance. After meta-analysis, phenomenological and study literature review identifying several relevant factors 
including external environmental forces, organizational capabilities, organizational learning, organizational structure, marketing strategy, innovation strategy, company size, marketing experience, $\mathrm{R} \& \mathrm{D}$ expenditure, marketing expenditure and government financial support. The fsQCA method consists of complex causality and tests asymmetrical relations between observations (Woodside, 2013). The research comprises 251 high tech firms by using fsQCA.

High tech firms that have better performance receive financial support and have a founder with marketing experience. In contrast, high tech firms do not have better performance, which these firms do not receive financial support and founders who lacks marketing experience and relevant $R \& D$ and marketing expenditure spending. The analysis of causal conditions reveals a relationship between a high tech firm's R\&D and marketing experience and the receipt of financial support by high tech enterprises. High tech enterprises that receive financial support and that have founders with marketing experience have better performance than those that lacking these attributes.

These findings have implications for decision makers, business incubators, public institutions, investors and other bodies that seek to foster performance for high tech companies. These practitioners of marketing and innovation strategy should promote and emphasize activities and practices that allow high tech firms to gain $R \& D$ and marketing experience. Thus, high tech companies can learn quickly and can efficiently use the knowledge they gain from working experience in their companies.

Relevant marketing experience is a key driver of better performance by high tech firms. Because marketing experience is important, past failure by a high tech firm is not an possible indicator of future failure. In fact, past failure provides high tech firms with experience and knowledge that helps them to avoid repeating the same mistakes form learning curve. Therefore, high tech firms with marketing experience make better use of financial support than high tech firms who lack marketing experience.

If government financial support helps high tech firms to enhance performance, then receiving these grants can helps high tech firms to grow. Indeed, high tech firms who benefit from financial support can potentially offer jobs to people and is unable to employ these individuals without financial support. Thus, policymakers should allocate more funding to subsidize high tech firms. Policymakers should not only encourage potential employee to study specific or official degrees at 
universities, but also promote R\&D and marketing courses within universities for students from all degrees. Such courses must be available to everyone regardless of resources or capabilities.

\section{References}

Aarikka-Stenroos, L., Sandberg, B., \& Lehtimäki, T. (2014). Networks for the commercialization of innovations: A review of how divergent network actors contribute. Industrial Marketing Management, 43(3), 365-381.

Ahuja, G. (2000). Collaboration Networks, Structural Holes, and Innovation: A Longitudinal Study, Administrative Science Quarterly, 45 (September), 425-55.

Barney, J. (1991). Firm resources and sustained competitive advantages, Journal of Management, 17 (1), 99-120.

Cai, L., Yu, X., Liu, Q., \& Nguyen, B. (2015). Radical innovation, market orientation, and risk-taking in Chinese new ventures: An exploratory study. International Journal of Technology Management, 67(1), 47-76.

Creswell, J. W. (2007). Educational research: planning, conducting, and evaluating quantitative and qualitative research (2nd ed.). Upper Saddle River, NJ: Merrill Prentice Hall.

Crossnan, M., Cunha, M. P. , Vera, D., \& Cunha, J. (2005). Time and organizational improvisation, Academy of Management Review, 30(1), 129-145.

Dewar, R. D., Dutton, J. E. (1986). The adoption of radical and incremental innovations: An empirical analysis, Management Science, 32 (11), 1422-33.

Dibrell, C., Craig, J., \& Hansen, E. (2011). Natural environment, market orientation, and firm innovativeness: An organizational life cycle perspective, Journal of Small Business Management, 49(3), 467-489.

Ettlie, J. E., Rubenstein, A.H. (1987). Firm size and product innovation, Journal of Product Innovation Management, 4, 89-108.

Fennell, M. L. (1984), Synergy, influence, and information in the adoption of administrative innovations, Academy of Management Journal, 27 (March), 113-29.

Gerwin, D. , Barrowman, N. J. (2002). An evaluation of research on integrated product development, Management Science, 48(7), 938-953.

Greve, H. R. (2003). A behavioral theory of R\&D expenditures and innovations: Evidence 
from shipbuilding. Academy of Management Journal, 46(6), 685-702.

Hurley, R. F, Hult, G.M. (1998). Innovation, market orientation, organizational learning: An integration and empirical examination, Journal of Marketing, 62 (3), 42-54.

Kindström, D., \& Kowalkowski, C. (2014). Service innovation in product-centric firms: A multidimensional business model perspective. Journal of Business \& Industrial Marketing, 29(2), 96-111.

Kotabe, M. (1990). Corporate Product Policy and Innovative Behavior of European and Japanese Multinationals: An Empirical Investigation, Journal of Marketing, 54 (April), 19-33.

Krishnan, Viswanathan, Karl Ulrich (2001). Product Development Decisions: A Review of the Literature. Management Science, 47(1), 1-21.

Lester, S. (1999). An introduction to phenomenological research. Retrieved from http://www.devmts.demon.co.uk/resmethy.htm.

Laforet, S. (2008). Size, strategic, and market orientation affects on innovation. Journal of Business Research, 61(7), 753-764.

Lukas, B. A.,Ferrell, O.C. (2000). The effect of market orientation on product innovation. Journal of the Academy of Marketing Science, 28 (Spring), 239-47.

Makkonen, H., \& Johnston,W. (2014). Innovation adoption and diffusion in business-to-business marketing. Journal of Business and Industrial Marketing, 29(4), 324-331.

Moorman, C.(1995).Organizational market information processes: cultural antecedents and new product outcomes, Journal of Marketing Research, 32 (4), 318-35.

Moorman, C., Miner, A. S. (1998). The convergence between planning and execution: improvisation in new product development, Journal of Marketing, 62, 1-20.

Moustakas, C. (1994). Phenomenological research methods. Thousand Oaks, CA: Sage Publications, Inc.

Parellada, F. S., Ribeiro, D., \& Huarng, K. H. (2011). An overview of the service industry futures (priorities: Linking past and future). The Service Industries Journal, 31(1), 1-6.

Ragin, C. (2008). Redesigning social inquiry: Fuzzy sets and beyond. Chicago: Chicago University Press.

Ragin, C.C. (2009). Qualitative comparative analysis using fuzzy sets (fs/QCA). In Rihoux, B., and Ragin, C.C.(Eds.). Configurational comparative analysis: Qualitative Comparative Analysis 
(QCA) and related techniques (Application social research methods). Thousand Oaks and London: Sage publications.

Rapp, A., Bachrach, D. G., Panagopoulos, N., \& Ogilvie, J. (2014). Salespeople as knowledge brokers: a reviewand critique of the challenger sales model. Journal of Personal Selling \& Sales Management, 34(4), 245-259.

Rubera, G., Ordanini, A., \& Calantone, R. (2012). Whether to integrate R\&D and marketing: The effect of firm competence. The Journal of Product Innovation Management, 29, 766-783.

Song, L. Z., \& Song, M. (2010). The role of information technologies in enhancing R\&D-marketing integration: An empirical investigation. Journal of Product Innovation Management, 27, 382-401.

Stock, R. M., Six, B., \& Zacharias, N. A. (2013). Linking multiple layers of innovation oriented corporate culture, product program innovativeness, and business performance: A contingency approach. Journal of the Academy of Marketing Science,41(3), 283-299.

Stuart, T. E. (2000). Interorganizational Alliances and the Performance of Firms: A Study of Growth and Innovation Rates in a High Technology Industry, Strategic Management Journal, 21, 791-811.

Vowles, N., Thirkell, P., \& Sinha, A. (2011). Different determinants at different times: B2B adoption of a radical innovation. Journal of Business Research, 64(11), 1162-1168.

Windahl, C. (2015). Understanding solutions as technology-driven business innovations. Journal of Business \& Industrial Marketing, 30(3/4), 378-393.

Woodside, A.G. (2013). Moving beyond multiple regression analysis to algorithms: Calling for a paradigm shift from symmetric to asymmetric thinking in data analysis and crafting theory. Journal of Business Research, 63, 483-472.

Woodside, A.G., Camacho, A.R., \& Lai, W.-H. (2013). Sense making, dilemma, and solutions in strategic management, International Journal of Business and Economics, 12(2), 91-95.

Woodside, A.G., Schpektor, A., \& Xia, X. (2013) Triple sense-making of findings from marketing experiments using the dominant variable-based logic, case-based logic, and isomorphic modelling, International Journal of Business and Economics, 12(2), 131-154.

Woodside, A.G. \& Zhang, M. (2013). Cultural diversity and marketing transactions: Are market integration, large community size, and world religions necessary for fairness in ephemeral 
$2^{\text {nd }}$ International Conference on Advanced Research in

exchanges? Psychology \& Marketing, 30(3), 263-276.

Wu, C. (2011). Global marketing strategy modeling of high tech products. Journal of Business Research, 64(11), 1229-1233.

Wu, C. (2013). Global-innovation strategy modeling of biotechnology industry. Journal of Business Research, 66(10), 1994-1999.

Table 1. Calibration of conditions

\begin{tabular}{|c|c|c|c|}
\hline Outcome/conditions & \multicolumn{3}{|c|}{ Calibration } \\
\hline \multirow[t]{8}{*}{ Performance(outcome) } & \multicolumn{3}{|c|}{ Calibrate function: } \\
\hline & \multicolumn{3}{|c|}{$0.05=$ total non-membership } \\
\hline & \multicolumn{3}{|c|}{$0.5=$ neither inside nor outside, total ambiguity } \\
\hline & \multicolumn{3}{|c|}{$0.95=$ total membership } \\
\hline & \multicolumn{3}{|c|}{ Cutoffs: } \\
\hline & \multicolumn{3}{|c|}{$0.05 \square \quad-3$} \\
\hline & \multicolumn{3}{|c|}{$0.5 \square \quad 0$} \\
\hline & \multicolumn{3}{|c|}{$0.95 \square \quad 4$} \\
\hline \multirow[t]{6}{*}{ Company size } & \multicolumn{3}{|c|}{$10,000 \quad$ employee above $\square 1$} \\
\hline & \multicolumn{3}{|c|}{ 6000-9999 employee $\square \quad 0.8$} \\
\hline & \multicolumn{3}{|c|}{ 3000-5999 employee $\square \quad 0.6$} \\
\hline & \multicolumn{3}{|c|}{ 1000-2999 employee $\square \quad 0.4$} \\
\hline & \multicolumn{2}{|c|}{ 100-999 employee $\square$} & 0.2 \\
\hline & 100 employee - & $\square$ & 0 \\
\hline \multirow[t]{6}{*}{ Marketing experience } & 20 years or more & & 1 \\
\hline & $15-19$ years & & 0.8 \\
\hline & 10-14 years & & 0.6 \\
\hline & $5-9$ years & & 0.4 \\
\hline & 1-4 years & & 0.2 \\
\hline & 1 year or less & & 0 \\
\hline $\mathrm{R} \& \mathrm{D}$ expenditure & \multicolumn{3}{|c|}{ Yes $\square 1$} \\
\hline (over $20 \%$ of expenditure) & \multicolumn{3}{|c|}{ No $\square 0$} \\
\hline
\end{tabular}




\section{icalinme}

$2^{\text {nd }}$ International Conference on Advanced Research in MUNICH, GERMANY BUSINESS, MANAGEMENT \& ECONOMICS

\begin{tabular}{c|c}
\hline Marketing expenditure & Yes $\square 1$ \\
(over 20\% of expenditure) & No $\square 0$ \\
\hline Government Financial support & Yes $\square 1$ \\
& No $\square 0$ \\
\hline
\end{tabular}

Table 2. Analysis of necessary conditions

\begin{tabular}{c|cc|}
\hline & \multicolumn{2}{|c|}{ fs_performance } \\
\hline Conditions tested: & Consistency & Coverage \\
f_ef & 0.806874 & 0.642051 \\
f_oc & 0.348288 & 0.808333 \\
f_ol & 0.845712 & 0.627805 \\
f_os & 0.223692 & 0.437000 \\
f_ms & 0.884124 & 0.628142 \\
f_is & 0.278093 & 0.557530 \\
ms_ef & 0.430442 & 0.657505 \\
ms_os & 0.665037 & 0.438710 \\
ms_ol & 0.806874 & 0.632057 \\
is_ol & 0.398288 & 0.508333 \\
\hline
\end{tabular}

Table 3. Possible combinations for performance

\begin{tabular}{|c|c|c|c|}
\hline & Raw Coverage & Unique Coverage & Consistency \\
\hline$\sim$ ef_oc $\cdot$ ol_os $\bullet \sim$ ms_is & 0.048250 & 0.047695 & 0.748542 \\
\hline ef_oc $\cdot \sim$ ol_os $\bullet \sim$ ms_is $\cdot$ oc_ol & 0.167365 & 0.177665 & 0.763158 \\
\hline ef_os $\bullet$ ol_is $\bullet$ oc_ol $\bullet \sim \mathrm{ms}$ _is & 0.263648 & 0.347839 & 0.859210 \\
\hline ef_ol $\bullet$ ol_os $\bullet$ os_oc $\bullet \mathrm{ms}$ _is & 0.329314 & 0.242406 & 0.781538 \\
\hline ol_os $\cdot$ ef_oc $\cdot \mathrm{ms}$ is & 0.322409 & 0.236187 & 0.788095 \\
\hline
\end{tabular}

Solution coverage: 0.724806

Solution consistency: 0.784507 
$2^{\text {nd }}$ International Conference on Advanced Research in

Table 4. Possible combinations for bad performance

\begin{tabular}{c|c|c|c}
\hline & Raw Coverage & Unique Coverage & Consistency \\
\hline of_oc $\cdot \sim$ ol_os & 0.082974 & 0.085972 & 0.886000 \\
$\sim$ ol_oc $\bullet \sim$ ol_os $\bullet \sim$ ms_is & 0.047455 & 0.086454 & 0.953000 \\
$\sim$ of_oc $・ \sim$ ol_os $\bullet$ is_ms $\cdot \sim$ is_ms & 0.073328 & 0.078328 & 0.957000 \\
\hline
\end{tabular}

Solution coverage: 0.637923

Solution consistency: 0.93074 